\title{
Feminist Distopyada İktidar, Baskı Ve Direniş: Damızlık Kızın Öyküsü
}

\author{
Öğr. Gör. Merve Deniz Pak ${ }^{1 *}$
}

Gelis tarihi: 07.08.2019

Kabul tarihi: 15.08.2019

\section{Atıf bilgisi:}

IBAD Sosyal Bilimler Dergisi

Sayı: Özel Sayı Sayfa: 1-11

Yıl: 2019

This article was checked by iThenticate. Similarity Index $2 \%$

1 Başkent Üniversitesi, Türkiye, mdpak@baskent.edu.tr

ORCID ID 0000-0001-7060-3729

* Sorumlu yazar
$\ddot{O} \mathbf{Z}$

Kadınların baskı ve tahakküm ilişkilerine direnişi edebi eserlere konu olmaktadır. $\mathrm{Bu}$ kapsamda dünya çapında ses getiren Damızlık Kızın Öyküsü isimli eser, doğurgan kadınların özgürlüklerini yok sayarak cinsiyete dayalı sosyal kast sistemi içerisinde iktidar ilişkilerini ve direniş mekanizmalarını distopik bir kurguyla anlatmaktadır. Gilead adı verilen aşırı muhafazakâr rejimde kadınların üzerindeki baskı ve korkuyu gözler önüne seren bu eser, feminist perspektifte tahakküm ilişkisinin baskı altına alınan sosyal çevre üzerindeki etkisini, baskıya direnememelerini ve baskıcı rejimin yeniden üretim biçimini işlemektedir. $\mathrm{Bu}$ yapı Neil Thompson'ın güç analizi bakıș açısı, Michel Foucault'un biyo-iktidar ve disiplin toplumu düşüncesi ve Paul Freire'nin baskı karşısında bireylerin tepkileri ile direniş mekanizmaları açısından değerlendirilebilir. Tüm bunlardan hareketle, bu çalışmada kadınların özgürleşme hareketi; totaliter bir rejimindeki iktidar, baskı ve korku yapıları ve bunlara karşı geliştirilen direniş mekanizmaları açısından incelenmiştir.

Anahtar Kelimeler: Feminizm, Kadın Hareketi, Biyo-iktidar, Baskı, Direniş 
Power, Pressure and Resistance in Feminist Dystopia: The Handmaid's Tale

\section{Lecturer Merve Deniz PAK ${ }^{1^{*}}$}

First received: 07.08.2019

Accepted: 15.08 .2019

\section{Citation:}

IBAD Journal of Social Sciences Issue: Special Issue Pages: 1-11 Year: 2019

This article was checked by iThenticate. Similarity Index 2\%

1 Baskent University, Turkey, mdpak@baskent.edu.tr

ORCID ID 0000-0001-7060-3729

* Corresponding Author

\begin{abstract}
Resistance to the relations of women's oppression and domination are the subject of literature. In this context, The Handmaid's Tale, which is influential around the world, ignores the freedom of fertile women and explains power relations and resistance mechanisms in a dystopic manner within a sex based social caste system. In the feminist perspective, this work, which reveals the oppression and fear of women in an over-conservative regime called Gilead, manipulates the effects of fear on society, how people are scared of raising their voices, and how the totalitarian regime reproduces itself through repression. This structure can be assessed in terms of Thompson's power analysis perspective, Foucault's bio-power and disciplinary society thought, and Freire's individual's reaction in pressure and resistance mechanisms. In this study power and fear structures in a totalitarian regime and the resistance mechanisms developed against them will be discussed in the emancipation movement of women.
\end{abstract}

Keywords: Feminism, Women's Movement, Bio-power, Pressure, Resistance 


\section{GíRIȘ}

Edebi çalıșmalar genellikle oluşturuldukları dönemin özelliklerini taşırlar ve aynı zamanda içinde bulundukları dönemdeki olayları ve yazarın bakış açısını yansıtırlar. $\mathrm{Bu}$ açıdan toplumsal sorunları gözler önüne seren edebi eserler, sistematik olarak incelendiğinde sosyal ilişkilerdeki duygu, düşünce ve eylemlerin anlaşılmasında önemli bilgiler sunmaktadır. Günümüz edebiyatına bakıldığında, eserler bir madalyonun iki yüzü olarak ütopya ve distopya şeklinde sinıflandırılabilir. Ütopya, "gerçekleşmesi olanaksız, çarpıcı, ilginç tasarı ya da düşünce" anlamına gelmekte olup daha çok insanların mümkün olan en ideal ve mükemmel yaşamı deneyimledikleri bir toplum ya da topluluk olarak sunulmaktadır. Ütopik eserler, toplumun o dönemdeki siyasi, sosyal ve kültürel sorunlarına öneriler getirerek ideal toplum ve devlet sistemini oluşturma amacı güderler (Nakiboğlu, 2015, s.381-407). Distopya ise "kötü, hastalıklı veya anormal" anlamını taşımakla beraber ütopyanın zıttı olarak düşünülmekte başka bir deyişle "anti-ütopya" olarak tanımlanmaktadır. Distopik eserlerde korkutucu ve sınırlayıcı rejimlerin olduğu, insanların zorlu koşullarda yaşamlarını devam ettirdiği, baskı, şiddet, hastalık, kirlilik ve yoksulluğun temsil edildiği ve bireysel özgürlüklerin ortadan kaldırıldığı bir dünya oluşturulur (Çelik, 2015, s.58-79).

Bu çalışmada, Margaret Atwood tarafindan kaleme alınan Damızlık Kızın Öyküsü (The Handmaid's Tale) adlı toplumsal cinsiyet esasina dayanan ve sosyal kast sistemini anlatan feminist distopya eseri ele alınmıştır. Eserde "Gilead" isimli aşırı muhafazakâr yönetimin sisteminin ülkenin yönetimini ele geçirmesiyle birlikte ortaya çıkan gerginlik, baskı ve korku konu edinilmektedir. Feminist bakış açısı ile ele alınan çalışma, korku kültürünün sosyal yaşam üzerinde yarattığı etkiyi, toplumun baskı ve zulüm karşısında direnememelerini ve baskıcı rejimin kendisini nasıl yeniden ürettiğini ifade etmektedir. Eserde sosyal olguların analizinde toplumsal cinsiyet kavramını dikkate alan alternatif ve eşitlikçi bir çerçeve sunulması amaçlanmakta; hak, eşitlik, insanın onuru ve değeri ile kadınların karar verme özgürlügünü elde etmelerinden doğan bir kadın hareketi temsil edilmektedir. Geleceğin anlatıldığ bakış açısıyla toplumsal cinsiyet rolleri bağlamında kadınlar marjinal bir grup olarak sunulmaktadır. Eser, hiçbir alanda özgür olamayan ve hayatta kalabilmek için kendi hikâyesini yeniden yazan ana karakter Offred'in ağzından anlatılmaktadır. Bu yönüyle söylemin ele alınması da kolektif dil, karşılıklı konuşma, düşünceler ve günlük aktivitelerde en sık kullanılan değerleri yansıtmakta; aynı zamanda düşüncelerin nasıl şekillendiğini de göstermektedir (Demir, 2013, s.55-69). Bu düzlemde eserde, hürriyetin hem fiziksel hem de zihinsel olarak kadınların ellerinden alınması ve iktidarın baskı unsuru olarak temsili, kadınların yaşam deneyimlerinin değerli olduğunu ve hikâyelerinin dinlenmesinin önemini ön plana çıkarmaktadır. Bu incelemede beden üzerinden bir kurgu oluşturulması ile beraber kontrol, disiplin, normalleştirme rejimleriyle kadın bedeninin anlamlandırılması ilgi çekici olmuş ve ataerkil iktidar biçimlerini ve beden kurgularını ele alan Foucault'nun felsefesi akıllara gelmiştir. Tüm bunlardan hareketle, bu çalışmada bir distopya olarak sunulan Gilead rejiminde kurgulanan iktidar ve baskı yapıları ile bunlara karşı direniş mekanizmaları incelenmiştir.

\section{Damızlık Kızın Öyküsü’ne Genel Bakış: Kitabın Tanıtımı ve Dönemin Özellikleri}

Margaret Atwood tarafından yazılan ve Türkçe'ye Damızlık Kızın Öyküsü (The Handmaid's Tale) olarak çevrilen kitabı, Kanada'da 1985 yılında basılıışır. Feminist distopya olarak kategorize edilen eser; doğurabilen kadınların egemen rejimin nüfus politikaları için baskı altına alınıp özgürlüğünden mahrum edilmesini odağına almaktadır. Bu odakta eserin yazıldığı dönemin etkilerini görmek de mümkündür. 1980'li y1lların son çeyreğinde Sovyetler Birliği’nin eski gücünü kaybedip yıkılmasın ardından kapitalist rejimlerin kuvvetlendiği belirtilmektedir. Benzer biçimde eser, Amerika Birleşik Devletleri'nde Sovyetler Birliği'ne karşı politika izleyen Ronald Reagan ile İngiltere'de "Demir Leydi" olarak bilinen başbakan Margaret Thatcher'ın iş birliği içerisinde olduğu döneme rastlamaktadır. $\mathrm{Bu}$ dönemde neoliberal politikaların sosyal yaşamda etkili olması ve buna paralel olarak Doğu Avrupa'da ve İngiltere'de sosyal politikalara ilişkin değişimlerin yaşanması, sosyal refah hizmetlerinin devlet eli yerine özel sektör tarafından sunulmaya başlaması ve sivil toplum hareketlerinin kısıtlanması meydana gelmiştir. Bu politik iklim içerisinde kadın hareketleri açısından İngiltere altın çağını yaşasa da; Thatcher, bu hareketin tam aksi biçimde toplumsal cinsiyet eşitsizliğini arttıran uygulamalar yapmaktadır. Orta Doğu’ya bakıldığında ise kadınların sosyal yaşamına adeta bir kâbus gibi çöken İran devrimi ve toplumsal değişimin kadınların aleyhine ilerlemesinin içselleştiği görülmektedir. Deyim 
yerindeyse tüm dünyada kadının değeri görmezden gelinmiş ve ataerkil yapılar devam ettirilmiştir. Fakat yine de bu sıralarda kadın hareketi devam etmektedir. Altmışlarda ve yetmişlerde artan bir şekilde süren ikinci dalga feminizm ise eşit hak feminizmi ve radikal feminizm olarak iki ayrı ideolojik harekete ayrilmıştır (Stillman ve Johnson, 1994, s.70-86). İkinci dalga feminizm, salt olarak hakların elde edilmesi ile kadınların yaşadıkları sorunların kökten bir biçimde çözülmediğini kabul ederek felsefesi daha radikal bir hal almıștır. Bu kapsamda ikinci dalga feminizmin amacı, sadece siyasi özgürlük değil tümüyle "kadının özgürleştirilmesi" olup "kişsisel olan politiktir" söylemi bu dönemde oluşturulmuştur. Bu bağlamda eşit haklar feminizmi; kürtajın yasal olması ve iş gücü, siyasi ve sosyal alanlarda kadınların ve erkeklerin eşitliğini hedeflemektedir (Gulick, 1991, s.57). Öte yandan radikal feminizm; toplumun temelde ataerkil yapıda inşa edildiğini hayatın tüm alanlarında kadınların erkeklerden daha aşağıda ve ikinci planda gösterildiğini ve bu yapının kırılmasında bilinç yükseltme odağında toplumsal cinsiyet rolleri üzerinde çalışılması gerektiğini ortaya koymuştur (Yin ve Yahya, 2013, s.14).

Eserin yazıldığı dönemdeki yapı ortaya konulduktan sonra güç ve baskının irdelenmesi için eserin kısa bir özetinin verilmesi faydalı olacaktır. Eser, Gilead Cumhuriyeti adı verilen Yeni Hristiyan hükümetinin ABD hükümetini devirerek kurduğu aşırı baskıcı politikalarıyla kadınların özgürlüğünü kısıtladığı bir dünya sunar. Sosyal sınıfların oluşturulduğu sistemde damızlık kızlar, eşler (doğurgan olmayan kadınlar), komutanlar (kocalar), gayrı-kadınlar, teyzeler (eğitimciler), melekler (askerler) ve gözler (gizli polisler) vardır. Diktatörlük ideolojileri ve toplumsal cinsiyet eşitsizliği baskın olan bu totaliter devlet; kısırlığa neden olan çevresel kirlilik ve kimyasal zehirlenme nedeniyle, karakterlerin yaşadığı ortamı, hareketlerini ve bilgilerini kontrol etmek için politikalar hazırlar. Bu kontrol mekanizmaları baskı odağında tasarlandığından büyük ölçüde etkili olur. Bu politikalardan biri olarak sosyoekonomik açıdan üst düzey ailelerin çocuk sahibi olmasını sağlamak için doğurgan dönemdeki kadınlar cinsel köle yani "damızlık kız" olarak sinıflandırılır. Bu kadınlar tüm hakları askıya alındıktan sonra, yeni Gilead ideolojilerini öğrenmek üzere Kızıl Merkez adı verilen yerde eğitim alırlar. Damızlık kızlar ailelerinden, çalışma alanlarından ve eğitim sisteminden uzaklaştırılır, onların herhangi bir şey okumaları engellenir, hizmet etmek için bulunduğu evden yalnızca kendisi gibi bir damızlık kızla beraber dışarı çıkabilir, "göz" adı verilen gizli polisler tarafından izlenir ve Gilead'ın dayattığı normların dışındaki sözleri söylemeleri veya eylemleri yapmaları durumunda öldürülürler. Rejimin en önemli yasakları kürtaj ve çocuk doğurmak için görevlendirildiği erkeğe sadık kalınmaması ve onun aldatılmasıdır. Eğer damızlık kızlar bu eylemleri yaparlarsa idama mahkûm edilirler ve cansız bedenleri halka gösterilir. Kadınların özgürlüklerinin yok sayıldığı bu yapı isimlerinin ve taşıdıkları geçmişin silinmesiyle görünür kılınır. Damızlık kızlar, hizmet verdikleri "komutanların isimleriyle" oluşturulan "-ki" (İngilizce'deki Of) ekiyle yeniden isimlendirilir ve burada "komutana ait" anlamına gelen bir kelime oyunu oynanır. Dahası, isimle beraber kimlik de görev alınan evde değişime uğratılır; önceden belirlenmiş roller ya da üniformalarla kadınlar kimliklerinden ve varoluşundan uzaklaştırılıp tek tipleştirilir. Örneğin; damızlık kızlar vücut yapılarını gizlemek için kırmızı kıyafetler giymek ve beyaz kanatları olan görüş alanını kısıtlayan başlıklar takmak zorundadır. Eşler sadece mavi, teyzeler yeşil, gayrı-kadınlar gri giyinmek durumundadır. Bu yapı içerisinde damızlık kızların yegâne özellikleri doğurganlıktır ve bu amaçla karanlık bir geleceğe mahkûm edilirler.

Eserin ana karakteri ve aynı zamanda hikâyenin anlatıcısı olan "Offred" de eşi (Luke) ve küçük kızından zorla koparılmıştır. Offred, çocuksuz bir çifte hizmet etmek amacıyla "Fred" isimli komutanla cinsel ilişkiye girmek ve çocuk doğurmak için alıkonulmakta; Serena Joy isimli eş, evin gündelik işlerinde görevli teyzeler Cora, Rita ve Nick adındaki şoförle yaşamaktadır. Offred'in bu evdeki tek görevi çocuk doğurmaktır. Rejimin kuralları gereği her cinsel ilişki, Offred'in, Serena Joy'un da cinsel ilişkiye dâhil olduğu "seremoni" adı verilen tecavüzle yaşanmaktadır. Bu sırada Fred eşi Serena Joy ile herhangi bir temasta bulunmamaktadır. Aynı zamanda Offred ile öpüşmesi, ona dokunması, tamamen soyunması ve duygu belirtisi göstermesi yasaklanmıştır. Fakat yasak olduğu halde komutan, Offred ile cinsel birliktelikten ziyade özel olarak zaman geçirmek ister. Bu da Offred'in komutanın odasına gitmesine ve kişisel ihtiyaçlarından doğan istediği şeyleri bu yolla elde edebilmesine imkân sağlamaktadır. Aynı zamanda Offred, evde çeşitli kısıtlamaların altında yaşamını sürdürmekte; sözde kendilerini eğiten ve aslında kontrol altında tutan teyzelere itaat etmekte; dışarı çıkabilmek için belirlediği çifti olan Ofglen ile sıklıkla alışverişe gitmektedir. Bu süreçte Ofglen ile Offred baskıya karşı direnmek ve Gilead'den kaçmak için fisıldayarak birbirleri ile konuşmakta ve "gözlerden" kaçmaktadırlar. Toplumda herkes 
birbirinden şüphe etmekte ve bu güvensizlik ortamı esas kontrol aracı olarak kullanılmaktadır. Belirli süreler içerisinde çocuk doğurması gereken Offred'in zamanı tükenmektedir ve bu nedenle doktorundan ve Serena Joy'dan başka erkeklerle (mesela Nick ile), ilişkiye girmesi için teklifler almaktadır. Serena Joy bunun karşıllı̆ında Offred'e kaybettiğini sandığı kızının fotoğrafını göstereceğini söyleyip kabul etmesini sağlamıştır. Baskıyı fark eden ve direnmek isteyen Offred hamile kalamadığı için kapatıldığı bir odada kendinden önceki damızlık kızın duvara yazdığı "Alçakların seni ezmesine izin verme!" cümlesiyle aynı hikâyeyi başka bir kadınla paylaştığını anlayarak kapatıldığı yerden çıkış yolunu aramaktadır. Bu sıralarda baskıdan kurtulmak için "Mayday" isimli bir yer altı örgütü kurulur; Moira isimli arkadaşları ise başkaldırışından dolayı geneleve gönderilir. Bu sırada Offred, komutanla daha sık gizlice görüşmeye başlamıştır. Komutan Offred için Serena Joy'un bir elbisesini ve makyaj malzemeleri ayarladığını ve onu gizlice dışarı çıkaracağını söyler. Offred, aylar sonra gece dışarı çıkacağı için ve damızlık kız elbiseleri dışında bir elbise giyeceği için çok heyecanlanır. Gilead rejimindeki kontrolleri atlattıktan sonra "Jezebel'in Yeri" adında bir geneleve giderler. Offred burada teyzelerin elinden kaçmayı başaran eski dostu Moira'yı görür ve tuvalette buluşup sohbet ederler. İlerleyen günlerde Serena Joy, komutan tarafından dolabından çalınan elbisesinin yakasındaki ruju görür ve Offred'in cezasını çekeceğini söyler. Offred, ihbar edileceğini düşünerek odasında intihar etmenin yollarını ararken infaz otobüsüne benzer bir otobüsün geldiğini görür. Odasında görevlileri beklerken, Nick gelir ve onların yeraltı direniş örgütleri olan Mayday'den geldiklerini, her şeyin düzmece olduğunu ve ses çıarmadan onlarla gitmesini söyler. Nick'e güvenmekten başka şansı olmayan Offred, kendini gelen kişilere teslim eder.

Bu çalışmada Margaret Atwood'un Damızlık Kızın Öyküsü isimli romanı totaliter bir rejim içinde yaşayan kadınların üzerinde kurulan biyo-iktidar ve baskı açısından içerik analizine tabi tutulmuştur. Sonraki bölümlerde bu bakış açısından elde edilen noktalar aktarılacaktır.

\section{Feminist Distopyada İktidar ve Baskının Analizi}

İktidar ve baskı, pek çok disiplin tarafından çeşitli şekillerde tanımlanmıştır. İktidarı yalnızca devletin ürettiği bir mekanizma olarak görmekten çıkaran Foucault (2000, s. 14) iktidarı; tahakküm kurma, yönlendirme, yönetme, hiyerarşi kurma, denetleme yapma, gözetleme, yasaklama ve zorlama kavramları ekseni etrafinda çok yönlü olarak ele almıştır. Foucault'ya göre (2000, s. 14) egemenlik, disiplin ve güvenlik olmak üzere üç temel iktidar analizi çerçevesi bulunmaktadır. Bu bağlamda "iktidarın yaptırım yolu ile devletin gücünü kullanması ve bu yol ile kanunlara itaati sağlaması ve normlara uygun davranan bireylerin ve toplumun üretilmesine olanak sağlayan standartlaşma, kontrol, ayrıştırma, mekânsal düzenleme, sınıflandırma ve akılcılaştırma gibi teknikler" analiz çerçeveleri yönünden yol göstericidir (Özcan, 2014, s.1-42). Foucault'ya göre (2000, s. 14) iktidarı analiz etmek için şu teknikler kullanılabilir:

- "İktidarı, kendisini düzenleyen ve sınırlandıran kuralların ötesine geçtiği, oluşturduğu ve kurumlarına yayıldığı yerlerde ve araçlarda aramak gerekmektedir.

- İktidarın temel motivasyonunu itaat ilişkileri bağlamında değerlendirmek ve "tam o anda işler nasıl olup bitiyor?" sorusuyla aramak gerekir.

- İktidar, hali hazırda mevcut ve dolaşımda olan ve sürekliliği takip eden işleyen bir şey olarak analiz edilmelidir. Bu koşullar altında iktidar ona boyun eğen ve onu uygulamak durumunda kalan bireyler açısından ele alınmalıdır. Çünkü iktidar var olabilmek için bireyleri kullanır ve bu yol ile kendisini var eder.

- İktidarın analizinde; küçükten büyüğe, merkezden çevreye, yerelden küresele uzanan bir analizinin yap1lması gerekir.

- Büyük iktidar mekanizmalarına eşlik eden ideoloji ürünlerini değerlendirmek gerekir. Bu noktada bilginin oluşumunu ve birikmesini, araçlarını, gözlem yöntemlerini, kaydetme tekniklerini, araştırma ve soruşturma prosedürlerini sorgulamak gerekir."

Thompson (2007, s. 15) ise güç kavramını ortaya koyarken özellikle güç ve insan etkileşimi arasındaki ilişkiyi vurgulamıştır. Bu yönüyle gücün ele alındığı bağlama göre hem olumlu hem de olumsuz yönlerinden, başka bir deyişle gücün zarar verebileceğinden ve aynı zamanda fayda sağlayabileceğinden 
söz etmiştir. Bu bağlamı her bireyin belirli bir gücü olsa da toplumdaki bazı bireylerin diğerlerine göre "daha güçlü" olmasına ve toplumdaki eşitsizlik derecesinin ciddiyetine odaklanarak kurgulamıştır. Bunlara ek olarak, bir toplumdaki baskı unsurlarını anlamak için sistematik değerlendirme yapılmasının faydalı olacağını ve bu süreçte şu hususların değerlendirilmesi gerektiğini ifade etmiştir:

\section{Demografik veriler}

\section{Mevcut sağlik hizmetleri sunumu}

3. Sosyal yardım kaynakları: Mevcut hizmetler, özellikle aile ve çocuk bakımı kurumları ve çocuk refahı kurumları, kabul prosedürleri ve hizmetten yararlanmak için bekleme süresi

4. Eğitim kaynakları: hizmetlere erişim, kabul politikaları ve mevcut özel hizmetler

5. Konut kaynakları: kamusal ve özel koşullar

6. Rekreasyonel imkânlar, kamusal ve özel gençlik hizmetleri tesisleri

7. Ek kaynaklar: adli sistemler, sosyal güvenlik sistemleri

8. Toplum özellikleri ve yapısı, baskının açık ve örtük mekanizmaları ve iktidar yapıları

Damızlık Kızın Öyküsü adlı roman iki tema çerçevesinde şekillenmiştir; ilk bölümde Offred'in Gilead Cumhuriyeti tarafından alıkonulması, damızlık kız olarak bir aileye verilmesi, burada yalnızca çocuk doğurmak için bulunması ve bu süreçte hem ilişkisel bağlamda yanında bulunduğu ailenin hem de toplumun tahakkümü altına girdiğini göstermektedir. İkinci bölümde ise Offred'in baskııı fark etmesi, direniş mekanizmalarını kendi benliğini yeniden inşa ederek diyaloglar kurması, örgütlü yapı içerisinde özgürlügünü yeniden kazanması söz konusudur. Bu bilgiler 1şığında Damızlık Kızın Öyküsü isimli eser baskı ve iktidar ile direniş ana temaları içerisinde değerlendirilebilir.

\section{Baskı, Korku ve İktidar: “Özgürlüğün Tadını Çoktan Kaybetmeye Başlamıştık”}

Foucault (1993, s.42), iktidar ilişkilerini analiz edebilmek için; iktidarın temel mekanizmalarının biçiminin ve mantığının mevcut kurumlarda ele alınmasını, başkaları üzerinde eylemde bulunmaya olanak tanıyan farklılaştırma sisteminin ve amacının değerlendirilmesini, baskı uygulamaya yönelik araçların keşfedilmesini, baskının kurumsallaşma biçimlerini ve süreçlerini incelemenin önemli olduğunu vurgulamıştır (Keskin, 2016, s.11-24). Bu çerçeveden hareketle, güç ve bask1 mekanizmalarının nasıl çalıştığı Damızlık Kızın Öyküsü isimli eser kapsamında değerlendirilebilir. Eserde, meydana gelen çevre ile ilişkili sorunlar sebebi ile doğum oranlarının azalması ve kısırlığın artması ve buna bağlı olarak kast sisteminde bulunan üst yapıdaki nüfusun tehlikeye girmesi sonucu rejim tarafından kadın bedeninin tahakküm altına alındığı görülmektedir. Bu düzlemde, iktidar mücadelesi ilk olarak mikro alanda kadın bedeni üzerine kurgulanmaktadır. Kontrol ilişkisine dayanan bu bağlam, Foucault (1994, s.8) tarafından "biyopolitik" olarak adlandırılmaktadır. Biyopolitik, yeni iktidar biçimi olarak devletlerin insanların bedenlerine müdahale etme ihtiyacı duyduğunu belirten bir kavramdır ve bu iki temel biçimde gerçekleşmektedir:

Birincisi; disiplinci iktidar biçimi şeklinde olup insan bedenine bir makine olarak yaklaşır. Kadın bedeni odağında doğurganlık ile ilişkili olan tüm teşvik ve kısıtlamaları, bedenin temsilini, ne kadar çocuk doğrulacağını, kadının bedeni üzerinde özgür bir irade yerine; "üst aklın" söz sahibi olmasını, nüfus ve aile planlamasını içeren tüm politikaları kapsar (Raouf, 2016, s.2395). "F" olarak adlandırılan diğer biçim ise bedeni doğal bir tür şeklinde konumlandırır; fakat yine de beden üzerine nüfusu düzenleyen bir denetim mekanizması içerisine yerleştirir. Biyo-iktidar, bedenin sahip olduğu güçlerin itaatkâr ve uysal kılınması gerektiğini ileri sürer. Foucault'nun Foucault (1994, s.27) "dispositif” olarak adlandırdığ1 "söylemler, kurumlar, mimari biçimler, düzenleyici kararlar ile beraber hukuk kuralları, idari kararlar, bilimsel, felsefi ve ahlaki önermelerden oluşan somut sistemler"; bedenin iktidar tarafından kuşatılması ve mikro-iktidarın tahakküm altına girmesi sonucunu doğurur. Bu sistemler ezme ve ezilme ilişkisine dayanan tahakküm ve hegemonya ilişkilerini odağına alan dışlama, ayrımcılık ve hiyerarşik yapı etmenlerini ortaya çıkarır. Bunun sonucunda da hukuk sistemi yerine toplumsal normlar giderek daha fazla önem kazanır. Kısacası yaşam üzerine odaklanan biyo-iktidar; bireyi oluşturulan norm ve kalıplara uygun davranmak zorunda bırakan "normalizasyon toplumu" oluşturur. 
Damızlık Kızın Öyküsü eserinde, kadın bedenine salt annelik vasfı yüklenmesi ve kadının varoluş amacının yalnızca doğurmak olması, kadının "kurban" rolünde olduğunu gözler önüne sermektedir (Aktarer, 2014, s.10). Baskının bu kadar yoğun olduğu bir rejimde kadının kendi sözünü söyleme hakkının olmamasının yanında "Kişisel olan politiktir" iddiası asla mevcut olamaz (Pettersson, 2010, s.6). Eserde kadının değersizliği ve ikinci planda oluşu yasalarla sabit kılınmış, erkeklerin kısır olamayacağı ve çocuğun olmamasının yalnızca kadınla ilgili olduğu normu geliştirilmiştir. Aynı zamanda, totaliter bir rejim söz konusu olup bir adli sistem mevcut değildir. Eserin yapısal özelliklerine bu açılardan bakıldığında, Gilead rejiminin mikro iktidar alanı olarak kadın bedeni üzerinden tahakküm ilişkisi kurduğu ve oluşturduğu mekanizmalarla bu sistemi devam ettirdiği görülmektedir.

Gücü yapısal modelde ele alan Thompson'a göre (2007, s.39) bir kişinin sınıf, etnik köken ve cinsiyet gibi çeşitli boyutlarda sosyal hiyerarşi içindeki konumu ve güç ilişkileri kaynaklara erişimi farklılaştırmaktadır. Aynı zamanda bu durum, gücün toplumda "doğal" karşılanması sonucu hegemonya biçimini aldığını ve gücün baskı unsuru olarak kullanıldığını işaret etmektedir. Yapısal ilişkiler boyutunda ise toplumdaki sosyal yapılar arasında eşitsizlik oldukça fazladır. Eserde de toplumsal bir norm olarak, komutanların eşlerinin güçlü kadınlar olduğu görülmektedir. Bu bağlamda sosyal yapıda eşler dışındaki tüm kadınların çalışmasının, eğitim almasının yasaklanması, çocuklarının ellerinden alınması ve doğurgan tüm kadınların çocuk sahibi olmayan kastın üst kısmında bulunan soylu komutanlara verilmesi, her kadının rolüne ve statüsüne göre giyinmesi, evdeki kadınların kendi alanının mevcut olması ve damızlık kızların bu bölgelere girmelerinin kesinlikle yasaklanması bir hegemonya oluşturmaktadır. Eserde erkekler her şeyi kontrol altında tutan birer mekanizma olsa da güç ilişkilerine bakıldığında Kızıl Merkez'deki eğiticilerin, teyzelerin ve eşlerin damızlık kızlar üzerinde güç kullandığı da görülebilir. Bu durum Foucault'ya göre "iktidarın bir merkezde toplanıp, orada vücut bulmadığı; bunun yerine iktidarın her yerde olduğu" düşüncesiyle; Freire'ye (2006, s. 22) göre ise "ezilenlerin ezme çabasında olmasıyla" ve baskının yeniden üretimiyle açıklanabilir.

Foucault biyo-iktidarı yasaklama, yok sayma ve suskunluk olmak üzere üç farklı pencereden ele almaktadır. Bu bağlamda Gilead Cumhuriyeti, "yaşamın" kendisini iktidarın bir nesnesi haline getirmesinden dolayı bir denetim toplumu oluşturmaktadır. Bu toplumda bireyler kapatmaya ihtiyaç duymadan, yanılsama altındaki özgürleşme pratiği içerisine alınarak normalleştiren nesnelere dönüştürülerek gözetlenmektedir. Gözetleme mekanizması olarak eserde "göz" adı verilen gizli yapılar, Foucault'un "Panoptikon" kavramsallaştırmasını akıllara getirmektedir. Panoptikon, geniş insan topluluklarını denetlemek ve işsizleri toplu çalışma disiplinine uyabilecek vicdanlı yurttaşlara dönüştürmek amacıyla her şeyi görünür kılındığı, sessiz kalma ve itaat etme mekanizmasının yürütüldüğ̈̈ bir yap1 oluşturma sürecidir (Wood, 2007, s.245-264). Bu yap1, daire şeklindeki cezaevlerinde olduğu gibi tüm bireylerin zaman kısıtlaması olmaksızın görülebildiği; hücrelerde bulunan mahkûmların, merkezde bulunan bir kule aracılığıyla ne zaman gözetlendiklerini hiçbir zaman bilemedikleri ve bu nedenle hal ve hareketlerini disipline ettikleri bir öz-kontrol mekanizmas1 kurmaktadır. Yok saymanın en çarpıcı örneği ise kadınların kendi isimlerinin kullanmalarının yasaklanması ve çocuk doğurması için görevlendirildiği erkeğe ait olduğunu gösteren biçimde çağırılmasıdır. Damızlık kızlar, geçmişleriyle bağlantıları koparılarak yeni bir kimlik inşa etmektedir. Örneğin Offred "Biz iki bacaklı rahimleriz, hepsi bu" diyerek kendi kimliğini "cisimleşme" üzerine oluşturmuş̧tur. $\mathrm{Bu}$ açıdan kimliğe saldıran bu sistem, bireyin değerine yönelen bir ezme ilişkisi olarak görülebilir. Benzer şekilde damızlık kızların erkekler tarafından sürekli izleniyormuş hissiyle yaşamalarından dolayı kendileri için hazırlanan özel kıyafetleri giymeleri ve görüşü kısıtlayan başlıklar takmalarından dolayı kimseyle iletişim kuramamaları bu otokontrole bir örnek olabilir. Aynı zamanda damızlık kızların sürekli gözetim altında oldukları düşüncesiyle aralarında fisıldayarak konuşmaları ve gözlerin kullandığı siyah minibüsleri gördüklerinde korkmaları bu mekanizmanın yarattığı baskının şiddetli olduğunu göstermektedir. Çünkü iktidarın oluşturduğu bu yapılara aykırı davranan bireyler ölümle cezalandırılmaktadır. Baskının bireyler üzerinde korku yaratması amacıyla halka açık düzenlenen infazlar ve sonrasında Kızıl Merkez'in duvarında sergilenen cansız bedenler; açıcça bir tehdit niteliğindedir ve baskıcı bir otokontrol mekanizması yaratmaktadır.

Freire'ye göre (2006, s.32), baskı altında olan insanların baskı ile mücadele edebilmek için öncelikle baskıyı fark etmeleri ve baskıya karşı eleştirel bilinç geliştirmeleri gerekir. Fakat sürekli baskı altında kalan ve bu döngüden kurtulamayan insanlarda; ezilme kader olarak algılanmaktadır. Foucault’ya göre 
(1994, s.8) ise din, politika ve devlet gibi kurumların yarattığı baskılardan dolayı toplumsal bir norm geliştirilir ve insanlar bu döngüden çıkamazlar. Eserde, baş karakter Offred de Gilead rejiminde içinde bulunduğu düzeni sorgulayamaz ve adeta baskıyı içselleştirerek ve normalleştirerek yaşadığı zorlukları normal bir durum olarak görür. Örneğin onun için çocuk sahibi olma "seremonileri" bir tecavüz veya şiddet değildir; sunulan seçeneklerden birini kabul ederek görevini yapmaktır. Offred bu süreçte Gilead toplumunun kurallarına alışma ve asimile olma yoluna gitmekte, bedeni üzerindeki kontrolünü yitirmekte ve kendisine yabancılaşmakta; sonuç olarak ise bedeninden ürkmeye başlamaktadır: "Bedenime bakmaktan kaçınıyorum, utanç verici ya da ahlak dışı olduğundan değil de onu görmek istemediğimden. Beni enine boyuna belirleyen bir şeye bakmak istemiyorum”.

Freire'nin (2006, s.25) baskıyı içinden çıkılamaz bir durum olarak değerlendirmesi; Offred'in de içinde bulunduğu baskıyı içselleştirmesi, umutsuzluğa kapılması ve yaşadığ 1 koşulları kader olarak görmesiyle benzerlik göstermektedir. Aynı zamanda baskının fark edilmeden sürdüğü ve normalleştiği de açıktır. Offred bu durumu eserde farklı şekillerde ifade etmektedir:

"Ellerim titriyor, neden korkuyorum? Hiçbir yasağı çiğnemedim, hiçbir söz vermedim, tehlikeye atılmadım, her şey güvenlikte. Beni korkutan bu seçme şansı, bir çıkış yolu, bir kurtuluş”. ölürsünüz."

"Hiçbir şey bir anda değişmez: derece derece ısınan bir küvette farkina varmadan haşlanarak

\section{"İstediğimiz her şeyi yapabiliriz. Düzeltiyorum: sinırlar dâhilinde"}

Toplumsal baskılar, insanların gerçek kimliğinden sıyrılarak büründüğü maskenin ardına saklanmasına ve gerçeklikten uzaklaşmasına neden olmaktadır. Bireylik yitimi yaklaşımı ile açıklanabilen bu durum; "bireysel kimliğe karşı kimliksizlik" ikileşimi üzerine inşa edilir. Kimliğine ilişkin yüksek farkındalık sahibi olan bireyin, baskının yoğun olduğu bir yapı içerisine girdiği andan itibaren kimliğinin yok olmasından ve bireyin kurban konumuna gelmesinden başka bir seçeneği kalmamıştır. Offred'in "özgürlügün tadını çoktan kaybetmeye başlamıştık, bu duvarları güvenli bulmaya başlamıştık” söylemi buna örnek olarak gösterilebilir. Baskının içselleştirilmesi ve normalleştirilmesi yalnızca damızlık kızlar için değil toplumdaki diğer sosyal sinfflardaki bireyler için de geçerlidir. Örneğin teyzelerin söylemlerinden olan aşağıdaki ifade bir mikro iktidar tezahürü olarak toplumda baskıya direnme mekanizmalarının olmadığını yansıtmaktadır:

Birden fazla özgürlük çeşidi vardır, derdi Lydia teyze. Bir şeyler yapma ve bir şeylerden sakınma özgürlüğü. Anarşi günlerinde, bir şeyler yapma özgürlügü vardı. Şimdiyse size sakınma özgürlüğ̈̈ veriliyor, azımsamayın bunu derdi. Ölmeye yüz tutmuş bir toplumduk biz, derdi Lydia teyze, çok fazla seçenek yüzünden. Stradan olan, derdi Lydia teyze, alıştığınız şeydir. Bu size şimdi sıradan görünmeyebilir, ama bir süre sonra öyle görünecektir, siradan olacaktır.

Foucault (2000, s.14) bilgi ve iktidar arasındaki ilişkiye de vurgu yaparak iktidarı tanımlar. İktidarı mantıksız bir güç olarak anlamaktan ziyade, bilgiye yön veren bir dirayet olarak görür. Bilgi üretimini normatif ve siyasal bir sorun olarak ele alır ve bilgiyi iktidardan bağımsız değerlendirmez. Foucault'ya (2000, s.14) göre bilgiyi üreten iktidar olduğundan iktidarın oluşturduğu bilgi, özgürleşmeyi engellemekte, bireyleri tanımlamakta ve disiplin altına almaktadır. Eserde bilgi üretme ve bilgiye ulaşma konusunda kadınların okumalarının, yazmalarının ve gündemden haberdar olmalarının yasaklanması yönünde atıflar vardır. Offred bu durumu şöyle ifade etmektedir:

"Bütün duvarlar kitap raflarlyla kapl. Kitapla dolu raflar. Kitaplar, kitaplar ve kitaplar, tamamen açıkta, ne kilit ne kutu. Buraya giremeyişimiz şaşırtıcı değil. Yasak olanın vahası burası."

Freire (2006, s.55) ise bilgiye erişimin kısıtlanmasını, ezenlerin bakış açısıyla yorumlamaktadır. Bu doğrultuda ezen-ezilen ilişkisinin sonlanmaması için iktidar ezilenlerin gerçekleri görmelerini; başka bir deyişle bilinç artırımını istememektedir. Eserde de eşlerin kontrolünde izlenmesine izin verilen televizyon kanalının devletin tekelinde olması ve sadece hükümet dostu içerikler yayınlaması, Gilead'a karşı örgütlü bir direniş haberi göstermemesi ve hakikatin saklanması bunun yansıması olarak örneklenebilir: 
"Serena da her zaman haberleri seyrettirir bize. Gerçi pek önemi yok; bu haberlerin doğru olup olmadığını kim bilir? Bunlar eski kayıt olabilir, sahte olabilirler. Gene de seyrediyorum, satır aralarını okuyabileceğimi umarak. Herhangi bir haber, şimdi, hiç olmamasindan daha iyi... Sadece zaferleri gösteriyorlar bize, yenilgileri asla. Kim kötü haber duymak ister ki? İnanmayı arzuladığımı şeyleri anlatıyor bize, çok ikna edici",

Fakat yine de Offred için bilginin önemi, komutanın odasına gittiği bir günde komutanın "ne alırsınız?" sorusuna yönelik "El losyonunun yanı sıra her şeyi bilmek istiyorum" demesiyle aslında hakikatin peşinde olduğunu ve direniş yönünde eylemlere yöneldiğini göstermektedir.

$\mathrm{Bu}$ bölümde iktidarın formları olarak hem disiplin hem de biyo-iktidarın gözetim, normalleştirme ve baskı yapısının farklı yansımaları ele alınmıştır. Feminist araştırmalar, kadınların bedenleri üzerinden yürütülen bu tahakküm biçimine yönelik direniş mekanizmalarının da çeşitli şekillerde olduğunu ifade etmiştir. Bir sonraki bölümde Damızlk Kızın Öyküsü isimli eser bu kapsamda değerlendirilmektedir.

\section{Direniş: "Alçakların Seni Ezmesine İzin Verme"}

Direniş, içinde yer almayı gerektiren muhalif bir hareket ve sosyal bir etkinlik olup otoriteye, baskıya ve iktidara yöneliktir. Foucault'nun direniş kavramına ilişkin tanımı, iktidar kavramı ile yakından ilişkilidir. Foucault, Cinselliğin Tarihi'nin birinci cildinde yetmişli yıllarda "mücadele" ve "direniş" kavramlarını eş anlamlı olarak kullanır. Güç ilişkisine meydan okumak için karşı koymaktan kaçınmak gerekmektedir; çünkü güç (iktidar), direnişten (karşı koymaktan) farklı değildir ve onunla beraber var olmaktadır (Iş̧1k, 2012, s. 103). Başka bir deyişle; iktidarın olduğu yerde zaten direniş de vardır. Foucault, bu bağlamı; feminizmde de kadının biyolojisinin kaderi olmaması gerektiği yönüyle sıkça vurgulamaktadır. Buradan hareketle kadınların baskıya direniş mekanizmaları oluşturmaları gerekliliği esastır.

Eserde Offred hamile kalamadı $\breve{g} 1$ için kapatıldığı bir odada kendisinden önce burada kalan damızlık kızın duvara yazdığı "Alçakların seni ezmesine izin verme!" anlamına gelen "Nolite te bastardes carborundorum" cümlesiyle aynı hikâyeyi başka bir kadınla paylaştığını anlayarak çıkış yolu aramaktadır. Offred bu durumdan kurtulmak için yeni bir benlik oluşturmalıdır. Bu nedenle yeni bir benlik inşa etmek için kendi hikâyesini yazmaya başlar ve dünyasını en baştan biçimlendirir. Yaşadığı baskıcı topluma başkaldırabilme yolu sadece budur ve toplumun gerçekliğine karşı bir anlatı yaratır. Atwood'un hikâyeyi Offred'in ağızından aktarması ataerkil yapının baskısına karşı direnişi sembolize etmekte ve Offred'in kadın olarak "kendi tarihinin hikâyesini (herstory)" yazabilmesine firsat tanımaktadır. Bu süreç Freire'nin (2006, s.70) de sözünü ettiği gibi ezilme ilişkisinin ortadan kaldırılması için öncelikle baskıyı fark etmek ve daha sonrasında ise eyleme geçmekle (praksis) mümkün olmaktadır. Offred'de değişime özgü ilk motivasyon cinsel yönden özgür olma eğilimleriyle başlar. Offred aşağıda yer alan ifadeden hareketle baskıya direnmek için düşüncelerini davranışa dönüştürür:

Kanatlarımızla, at gözlüklerimizle yukarı bakmak zor, tamıyla görmek zor, gökyüzünü, herhangi bir şeyi. Gene de bunu yapabiliyoruz, her seferinde bir anllğına, başın yukarı ve aşağı, yana ve geriye doğru hızlı bir hareketiyle. Dünyayı kaçamak anlarda görmeyi ögrendik.

Offred'in kendi isteği doğrultusunda istediği biçimde ve istediği kişi ile birlikte olabilme isteği, aklına bağımsız olabilme yönünde bir kıvılcım düşürür. Örneğin erkek korumaların ona bakması ve Nick ile beraber olması, erkekler tarafindan hoş karşılanması ve bunu bilmesi onu mutlu eder. Fakat tüm bunlar, Gilead toplumu tarafindan son derece radikaldir ve bu yönü ile bir direniş biçimidir.

Offred baskıyı fark etme ve eyleme geçme sürecinde geçmişini sıklıkla düşünmektedir. Freire (2006, s.71), bu noktada ezilenlerin "ancak ezildiklerinin ve kendi güçlerinin farkına vardıklarında" özgürleşme sürecine girmiş olduklarını ve "özgürleşme için örgütlü mücadeleye girdiklerinde" kendilerine inanmaya başladıklarını ifade eder. Eserde de Offred'in annesinin ve arkadaşı Moira'nın kendisini özgürlüğe teşvik eden destekçiler haline geldiği görülmektedir. Çünkü her ikisi de karşılaştıkları baskılara direnmişlerdir. Offred'in annesi gençlik çağında aktif olarak kadın hareketlerinde rol almıştır. Offred'in Gilead rejiminden önce özgür bir geçmişe sahip olması, elinden neyin alındığının bilincinde olmasını sağlamakta ve yeni bir kimliğin inşası için birer yapı taşını oluşturmaktadır (Staels, 1995, s.455). Offred çocukluğunda porno dergilerini annesiyle beraber yaktığını, annesiyle izlediği filmlerde "Seçme 
özgürlüğü. Her bebek istenilmiş bir bebek olsun. Bedenlerimizi geri verin. Bir kadının yerinin mutfak masası olduğuna $m \iota$ inanıyorsunuz?" şeklinde söylemlerin olduğunu ve annesinin şu sözlerini hatırlamaktadır:

Siz gençler, hiçbir şeyin değerini bilmiyorsunuz, derdi annem. Sizi sadece bulunduğunuz yere getirmek için neler çektiğimizin farkında değilsiniz, şu kadarcık yol almak için bile kaç tank, kaç kadının yaşamını ve bedenini ezip geçti, biliyor musunuz?

Offred'in direnişinde annesi ile beraber arkadaşı Moira'nın da etkisi vardır. Moira, çalıştırılmak üzere damızlık kız olarak baskıcı rejim tarafından ele geçirilmiştir. Ancak buna direnmiş; kendisini takip eden göz ve teyzelerden kaçmanın yolunu bulmuştur. Sonrasında ise gece kulübüne dönüştürülen bir mekânda çalışmaya başlamıştır ve bunu bir tür özgürlük olarak nitelendirmiştir. Offred de Moira'dan etkilenerek toplum tarafından kendisine dayatılan görev ve kimliği yıkıp kendi varoluşunu yeniden inşa etmeye çalışır. Bu sebeple, eserde de pek çok kez "yeniden inşa" ifadesi geçmektedir. Moira'nın da içinde bulunduğu Mayday isimli grubun baskıya karşı örgütlenmesi ve Offred'i de bu sürece dâhil etmesi kolektif bir mücadeleye örnek olarak gösterilmektedir. Aynı zamanda benzer baskıyı yaşayan kadınların temel hak olan "kendi sözünü söyleme hakkını" elde etmek için de çabaladıkları görülmektedir. "Susturulanlar duyulmak için yaygara koparacaklardır, sessizce de olsa" söyleminden yola çıkarak oluşturulan bu örgüte aynı zamanda Freire'nin (2006, s.73) diyalog kavramsallaştırmasından bakılabilir. Buna göre; birlikte öğrenmek ve birlikte eylemde bulunmak önemli ve vazgeçilmezdir. Offred bask1 altında olsalar bile örgütlenme noktasında diyalog kurduklarını şöyle ifade etmektedir:

Neredeyse sessiz fisıldamayı ögrendik. Yarı karanlıkta kollarımızı uzatabiliyor, teyzeler bakmazken, boşluğu aşıp birbirimizin ellerine dokunabiliyorduk. Dudak okumayı da öğrendik, başlarımız yastığa yapışık, yana dönmü̈s, birbirimizin dudaklarını gözleyerek. Bu biçimde isimlerimizi unutmadan ilerliyorduk.

\section{Sonuç}

Margaret Atwood'un Damızlık Kızın Öyküsü adlı eserinde feminist bir distopya kurgulanmıştır. Başkarakter Offred'in anlatımıyla Gilead Cumhuriyeti'nde yaşayan pek çok kadının fiziksel ve zihinsel olarak özgürlüklerinin ellerinden alındığ 1 görülmektedir. Offred, kendi hikâyesini yaşarken aynı zamanda anlatmakta; zihninde sesini ve kimliğini yeniden inşa ederek baskıdan kurtulmaktadır. Eserde kadın bedeni üzerinden iktidarın ve baskının yaratıldığı görülmektedir. Korku rejiminin hâkim olduğu düzende gücü elinde bulunduranlar; herhangi bir direniş veya kural ihlalinde ciddi yaptırımlar uygulamakta ve bu şekilde iktidarlarını sürdürmektedir. Bu süreçte din, devlet ve evlilik gibi kurumsal yapıların baskı unsuru olarak kullanılması da göze çarpmaktadır. Tüm bunlar değerlendirildiğinde kadının güçsüzleştirilmesi gündeme gelmektedir.

Sonuç olarak eser, Thompson'ın (2007, s.50) "yapabilme gücü” (power to), "gücü bask1 olarak kullanma" (power over), "iş birliğine dayalı güç" (power with) ve "özden gelen güç" (power from within) olarak sınıflandırdığı gücün kavramsal çerçevesinden değerlendirilebilir. Yapabilme gücü, kişinin hedefine ulaşmasında sahip olduğu potansiyelini belirtmektedir. Eserde devletin sosyoekonomik olarak üst kesimde bulunanların soyunun devam ettirebilmesi için mevcut devlet düzenini yıkarak, totaliter bir rejimle doğurgan kadınlar üzerinde tahakküm kurduğu görülmektedir. Aynı zamanda güç baskı unsuru olarak kullanılmakta; itaat ilişkisi yaratmakta ve bu baskı kişisel, yapısal ve toplumsal düzeylerde meydana gelmektedir. Gilead Cumhuriyeti sahip olduğu denetleme (gözler), gözlem, disiplin ve ceza gibi çeşitli mekanizmalarla gücü elinde bulundurmakta ve yeniden üretmektedir. Benzer şekilde cinsiyete dayalı sosyal kast sisteminden dolayı güç dengesizlikleri yaşanmakta ve gücü elinde bulunduranlar diğeri üzerinde tahakküm kurabilmektedir. Bask1 altındaki kadınlar ise bu iktidar karşısında güçsüz duruma getirilmiş ve sahip oldukları her şey ellerinden alınmıştır. İşbirliğine dayalı güç ise gücün oluşmasında ortaklık temelini yani kolektifliği odağına alır ve birlikte çalışarak veya birlikte çalışmayı teşvik ederek amaca ulaşmayı hedefler. Gilead Cumhuriyeti'nde baskılar karşısında örgütlü direniș hareketleriyle iş birliğine dayalı güç kullanılmıștır. Benzer baskılara maruz kalan kadınlar, seslerini çıkarabilmek için Mayday isimli kadın hareketini başlatmışlardır. Özden gelen güç ise zorlayıcı durumlar karşısında dayanıklılık, esneklik, tinsellik ve otantiklik (sahici olma) kavramlarını 
karşılamaktadır. Esere bu perspektiften bakıldığında, Offred'in kendi kimliğini ve hikâyesini yeniden inşa etme sürecinde bütünlüğünü koruyabildiğini ve böylece kendini güçlendirdiğini söyleyebiliriz.

\section{KAYNAKÇA}

Aktarer, S. (2014). Kurbanlıktan Kurtuluşa: Margaret Atwood'un Kadın Başkahramanlarına Feminist Bir Yaklaşım. Yayımlanmamış yüksek lisans tezi, Atatürk Üniversitesi, Erzurum.

Atwood, M. (2017). Damızlık Kızın Öyküsü. İstanbul: Doğan Kitap.

Çelik, E. (2015). Distopik romanlarda toplumsal kurgu. Sosyoloji Araştırmaları Dergisi, 18(1), 58-79.

Demir, G.C.(2013). Michel Foucault'da söylem ve iktidar. Kaygı Dergisi, 21, 55-69.

Foucault, M. (1992). Hapishanenin Doğuşu. Ankara: İmge Kitabevi.

Foucault, M. (1993). Cinselliğin Tarihi I. İstanbul: Afa Yayınları.

Foucault, M. (1994). Özne ve İktidar. İstanbul: Ayrıntı Kitabevi.

Foucault, M. (2000). Büyük Kapatılma. İstanbul: Ayrıntı Kitabevi.

Foucault, M. (2000). Entelektüelin Siyasi İşlevi. İstanbul: Ayrıntı Kitabevi.

Freire, P. (2006). Ezilenlerin Pedagojisi. İstanbul: Ayrınt1 Kitabevi.

Gulick, A.M. (1991). The Handmaid's Tale By Margaret Atwood: Examining Its Utopian, Dystopian, Feminist And Postmodernist Traditions. Yayımlanmamış yüksek lisans tezi, Iowa State University, ABD.

Iş1k, S. (2012). Foucault'da iktidar, özgürlük ve direniş. EKEV Akademi Dergisi, 51, 103-114.

Keskin, F. (2016). Foucault'nun özne ve iktidar kavramları üzerine. 10 Ağustos 2018 tarihinde http://www.cangungen.com/2011/08/11/foucaultun-ozne-ve-iktidar-kavramlariustune-ferda-keskin/ adresinden erişildi.

Nakiboğlu, G. (2015). Ütopyadan Doğmak, ütopya doğurmak: heterotopya kavramı ve heterotopya bağlamında balık izlerinin sesi. FSM İnsan ve Toplum Bilimleri Dergisi, 5, 381-407.

Özcan, K. (2014). Yönetsel kontrol ve örgütsel düzen: Michel Foucault ve Zygmunt Bauman ekseninde bir tartışma. Amme İdaresi Dergisi 47(2), 1-42.

Pettersson, F. (2010). Discourse and Oppression in Margaret Atwood's The Handmaid's Tale. Yayımlanmamış doktora tezi, Linnaeus University, ABD.

Raouf, C.G. (2016). Reclaiming body and mind in Margret Atwood's The Handmaids Tale. Research Journal of English Language and Literature, 4(3), 2395-2636.

Staels, H. (1995). Margaret Atwood's The Handmaid's Tale: resistance through narrating. Journal of English Studies, 76(5), 455-467.

Stillman, P. ve Johnson, A. (1994). Identity, complicity, and resistance in The Handmaid's Tale. Utopian Studies, 5(2), 70-86.

Thompson, N. (2007). Güç ve Güçlendirme. Ankara: Nika Yayınları.

Wood, D.M. (2007). Beyond the panopticon? Foucault and surveillance studies. Space, Knowledge And Power: Foucault And Geography, (eds. J. Crampton, S. Elden), 245-264. Aldershot: Ashgate.

Yin, C.P. ve Yahya, W.R. (2013). Freedom in Margaret Atwood's novel the Handmaid's Tale. Arts, Social Sciences, 15(2),14-26. 